\title{
ENTRETONS: A LUZ E AS TREVAS
}

\section{ENTRETONS: LIGHT AND DARKNESS}

\author{
Aurora Cardoso de QUADROS*
}

\begin{abstract}
Resumo: Este artigo propõe reflexões a respeito da associação entre povos indígenas brasileiros, a catequese e a literatura do Padre José de Anchieta em missão no Brasil. Por meio da leitura, análise e pesquisa bibliográfica, observa-se que o nome do Padre José de Anchieta, ao mesmo tempo em que se associa à catequese dos primeiros habitantes da terra colonizada, relaciona-se também às bases da sua literatura e, nesse sentido, seus escritos se distinguem dos registros de outros nomes de destaque nos primórdios da colonização. Fazendo da arte seu principal instrumento de persuasão, escreveu poemas, autos e cantos, que usou para converter os silvícolas. Seu modo de defender e conviver com eles o tornou símbolo do bom jesuíta, mas sua atuação a serviço da ideologia católica à qual era fiel consiste em uma performance antagônica à cultura desses povos. Nesse sentido, o efeito da catequese, mesmo em se tratando do padre canarinho, querido das tribos pela visão diferenciada e pelo modo de agir distinto da maioria dos missionários do período, foi de inegável violência simbólica, nos termos de Pierre Bourdieu, autor usado como aporte teórico neste estudo.
\end{abstract}

Palavras-chave: Anchieta. Literatura. Catequese. Luz e treva. Violência simbólica.

\begin{abstract}
This paper proposes reflections about the association between Brazilian indigenous people, catechesis and the literature of the Father José de Anchieta on mission in Brazil. Through reading, analysis and bibliographic research, it is observed that the name of Father José de Anchieta, while associated with the catechesis of the first inhabitants of the colonized land, is also related to the bases of Brazilian literature and, in this sense his writings are distinguished from the writings of other prominent names in the early times of colonization. Making art his main instrument of persuasion, he wrote poems, texts and songs, which he used as a resource for the desired conversion. His way of defending and living with them made him a symbol of the good Jesuit, but his performance in the service of the Catholic ideology to which he was faithful consists of an antagonistic performance to the culture of these people. In this sense, even in the case of the priest from the Canary Islands, who was dear to the tribes for having a vision and way of acting different from most missionaries of the period, the effect of catechesis was of undeniable symbolic violence, in the terms of Pierre Bourdieu, author used as theoretical contribution in this study.
\end{abstract}

Keywords: Anchieta. Literature. Catechism. Light and darkness. Symbolic violence.

\section{As alianças e os ecos medievais}

A produção escrita jesuítica no Brasil está relacionada ao trabalho missionário de catequese, de colonização e de informação, em cuja conduta, conforme se pode ler em Jacques Le Goff (2008), se estendem as luzes e as sombras do medievalismo. Segundo o francês, ainda vigoravam nas camadas sociais, sejam os indivíduos nobres ou os comuns, as lições de

*Doutora em Teoria Literária e Literatura Comparada pela Universidade de São Paulo - USP. Professora do Departamento de Comunicação e Letras da Universidade Estadual de Montes Claros (UNIMONTES). E-mail auroracardoso2010@hotmail.com 
afabilidade, os valores morais e em que apenas "a palavra civilização integrava harmoniosamente os valores de cima e os valores de baixo" (LE GOFF, 2008, p. 125, grifo do autor). Tais valores, presentes nos registros de então, a partir dos sermões dos pregadores e dos escritos informativos consistem em diretriz que inicialmente guia as tendências da Igreja Católica, no período em que ela investia na reação contra a Reforma. Insere-se sua doutrina, contudo, na demanda portuguesa do período em que se fazia importante solidificar o poderio de Portugal e não apenas expandir a sua fé católica. Os movimentos acontecidos na Europa e de que participaram a Igreja Católica e o Estado português, que vieram a motivar os "novos católicos" posteriormente, desencadearam questões ideológicas advindas da Idade Média. A fase, reprovada como uma época tirânica, de degradação e violência, que acarretaria uma desordem política global, motivou novos ideais de renovação da fé cristã, conforme atesta Dirce Lorimier Fernandes (2004). Nesse fluxo é que as navegações, em busca de novas terras, eram impulsionadas pelo desejo de expansão do poderio e da religião. No Brasil, colonizado pelo imperialismo e catolicismo portugueses, tal demanda fica expressa desde a Carta, de Pero Vaz de Caminha, décadas antes da chegada de Anchieta à nova terra, em que fica evidente o interesse exploratório do Reino português e em que se antecipa a necessidade da catequese dos nativos. Dentre muitos atributos, a carta de Caminha já antecipa a revelação do elo entre Portugal, a Igreja e o papel de ambos na expansão do catolicismo. A visão que Pero Vaz exprime, contudo, não ultrapassa os limites superficiais das primeiras impressões, em muito desmentidas posteriormente quando, de fato, as missões vêm ao Brasil para a referida transformação religiosa. Segundo a carta, os tupiniquins eram dóceis e amigáveis, sendo uma gente "boa e de bela simplicidade" (CAMINHA, s/d, p. 30) que logo se mostraram solícitos e gentis. Em vários momentos, observa-se a pacífica adesão com que seguiam os portugueses:

\footnotetext{
Nesse dia, enquanto ali andavam, dançaram e bailaram sempre com os nossos, ao som de um tamboril nosso, como se fossem mais amigos nossos do que nós seus. Se a gente lhes acenava, se queriam vir às naus, aprontavam logo para isso, de modo tal que, se os convidávamos a todos, todos viriam (CAMINHA, s/d, p. 30).
}

O viajante português relata, também, suas impressões sobre o paganismo dos gentios, expressando a necessária conversão à fé católica, pelo batismo, o que aparentemente, segundo ele, seria fácil, devido a docilidade e pureza daquela gente:

E segundo o que a mim e a todos pareceu, esta gente, não lhes falece outra coisa para ser toda cristã, do que entenderem-nos, [...] pareceu a todos que nenhuma idolatria nem adoração têm. E bem creio que, se Vossa Alteza aqui mandar quem entre eles mais devagar ande, que todos 
serão tornados e convertidos ao desejo de Vossa Alteza. E por isso, se alguém vier, não deixe logo de vir clérigo para os batizar (CAMINHA, s/d, p. 32, grifo nosso).

Caminha data a carta de 01 de maio de 1500, situando-a no primeiro ano do século. Sua visão aproxima-se do que seria descrito décadas depois por Michel de Montaigne (1980), que reporta a partir do relato de um homem simples e grosseiro que convivera com gentios e contara a ele sua experiência no Novo Mundo. Infere o francês, inicialmente ironizando o julgamento equivocado do europeu civilizado e depois o comparando em inferioridade ao habitante nativo do Novo Mundo:

[...] só podemos julgar da verdade e da razão de ser das coisas pelo exemplo e pela idéia dos usos e costumes do país em que vivemos. Neste a religião é sempre a melhor, a administração excelente e tudo o mais perfeito. A essa gente chamamos selvagem como denominamos selvagens os frutos que a natureza produz sem intervenção do homem. No entanto, aos outros, àqueles que alteramos por processos de cultura e cujo desenvolvimento natural modificamos, é que deveríamos aplicar o epíteto (MONTAIGNE, 1980, p. 101).

Em meados do mesmo século (1549), a ordem a que pertencia o Padre Anchieta, os jesuítas, chega ao novo território, brandindo a bandeira da fé católica, à luz da bula Regimini militantis ecclesiae (O Governo da Igreja Militante) da Companhia de Jesus. Ainda que já tivessem chegado outros religiosos anteriormente, os jesuítas encontram o primitivo ainda em estado natural, de convívio direto com a natureza. Considerando-se a meta de doutrinação dos habitantes nativos pela catequese e pela mesma ideia apontada por Caminha de salvação desses habitantes pela fé católica, os jesuítas precisaram utilizar recursos variados para doutriná-los. Mas o que predominou, sob a bandeira da Companhia de Jesus e de Portugal, como se sabe a partir da história e da dizimação ocorrida, foi a supremacia do colonizador. E, esse domínio do autóctone das novas terras pelos colonos estrangeiros será registrado pela própria correspondência do padre Anchieta, em várias cartas, tratando da escravidão indígena como natural, bem como a salvação pela fé, que é apontada como necessária:

Quanto aos escravos dos portugueses, Índios da terra, desde que o Brasil é povoado nunca se disse missa nem por cura nem por mandado do Bispo algum por respeito deles, antes em partes onde não há casas da Companhia nunca a ouvem, nunca por cura foram confessados porque lhe não sabem a língua (ANCHIETA, 1997, p. 330).

Ele testemunha e, de certo modo, renega a ação geral dos seus pares, mas revela também que a catequese não se procedeu pelos meios pacíficos. Enquanto o trabalho indígena era sua coibição física, buscando escravizar os corpos para arrancar-lhes o rendimento, a conversão ao 
catolicismo se deu por meio da coibição espiritual, atuando no espírito do indivíduo e inculcando valores alheios em sua consciência. Dessa forma, pode-se entender que Anchieta serviu à Igreja Católica, que, pela violência simbólica, nos termos de Pierre Bourdieu (2001), induziu o nativo a se converter aos ideais do novo povo e abandonar as práticas vigentes das suas tradições, crenças e cultura.

As empreitadas das Missões incluíam “arrebanhar” e conduzir os cativos ou voluntários para o trabalho nas cidades ou em fazendas, onde fariam serviços gerais ou trabalhariam nos engenhos de açúcar, conforme estudos de Carlos Alberto Zeron (2020). Nos colégios jesuítas, como explica o historiador, educava-se na doutrina católica. Os recursos utilizados por José de Anchieta nessa ação doutrinária foi a criação do teatro, definindo como foco a temática dos episódios bíblicos. Como estratégia, ele inicialmente aprendeu a língua tupi, utilizando-a para maior eficácia no aprendizado dos gentios, que não apenas assistiam nem apenas ouviam, mas representavam, dançavam e cantavam. Esse detalhe diferencia-o da maioria, em cujos equívocos incluíam prédicas em latim e sacramentos sem qualquer explicação, conforme será dito aqui. É de se notar, nesse contexto, a importância da palavra, que era instrumento nas manifestações dos autos, nos cantos que ora acompanhavam as dramatizações, ora eram apenas performances musicais, mas quase sempre de temática religiosa, sobretudo marial. Nas criações artísticas a respeito de Maria, com que os missionários buscavam a adoração desta pelos gentios, pode-se identificar a engrenagem que vai envolvendo aqueles povos de costume politeísta nas novas disposições do jogo social (BOURDIEU, 2001), fazendo presumir hoje as bases do atual preconceito com os povos originários do Brasil. Ainda que em toda estrutura haja organicamente o jogo das coerções no exercício dos seus papéis, o jugo do indígena foi justificado por uma suposta inferioridade, conforme aponta a Carta de Caminha. A percepção unilateral determinante dessa inferioridade pode ser analisada a partir de "mecanismos constitutivos de jogos sociais tão envoltos pelo prestígio e mistério como os da arte, da literatura, da ciência, do direito ou da filosofia, e depositários de valores em geral tidos como os mais universais e os mais sagrados." (BOURDIEU, 2001, p. 16). Assim, a ideologia e a arte fariam parte do mesmo campo devido ao seu funcionamento dos fatores de prestígio e "superioridade". A escrita de informação de Anchieta também revela a ideia da superioridade católica.

Porém, cumpre ponderar aspectos que desfazem os limites da radicalidade na valoração do padre canarinho, pois este se destaca dos demais pela forma de atuação. É certo que as crônicas de informação constituem os primeiros escritos sobre a vida na nova terra, seus habitantes e sua natureza. Os registros, feitos por viajantes europeus e missionários tinham por 
objetivo fornecer informações de aspectos importantes sobre o Brasil. Os cronistas informam sobre as belezas que se estendem da região costeira ao interior, cuja "prodigiosa mutabilidade dos aspectos do céu e do solo escapa a qualquer definição.” (ROMERO, 1960, p. 274). Embora vistas por alguns estudiosos como indiferentes no conjunto da produção literária brasileira, Alfredo Bosi considera que tais crônicas do período colonial valem como reflexo da visão do mundo dos nossos primeiros observadores, acrescentando que "graças a essas observações diretas da paisagem, do índio e dos grupos sociais nascentes, que captamos as condições primitivas de uma cultura que só mais tarde poderia contar como o fenômeno da palavra-arte" (BOSI, 1974, p. 15). Entende-se com isso que os registros coloniais possibilitam o regresso dos interessados, de poetas e escritores às raízes primitivas. E o povo indígena, como se sabe, tornase o principal eixo de identidade quando se trata da construção da brasilidade empreendida pelos projetos literários. A diferença é, de fato, o modo de atuação. Neste ponto não se contesta a natureza singular do padre Anchieta, que usou a palavra/arte na catequese. E a palavra literária, enquanto representação, revela tanto a arte quanto as ideias, mas revela também suas concepções e valores.

Segundo Sérgio Buarque de Holanda, "a expressão de semelhantes tendências corresponde a fenômenos individuais" (HOLANDA, 1991), cujo aprofundamento seria difícil mesmo às testemunhas oculares. Como membro de destaque da Companhia de Jesus, Manoel da Nóbrega lidera o grupo a que inicialmente se juntou o Padre Anchieta. Esse logo começa o trabalho em Piratininga, onde funda a cidade de São Paulo, e o ensino da língua portuguesa facilitaria a comunicação. O colégio ali fundado torna-se o instrumento para educação de portugueses e autóctones, consistindo num posto missionário da Companhia de Jesus no meio de uma região indígena. Anchieta empenha-se na conversão dos povos originários e na sua defesa contra os ataques e maus tratos por eles sofridos. Em torno desses e de outros personagens centrais, o quadro geral da colônia revela pelos escritos do período as várias forças antagônicas, bem como as variadas ideologias. Ocorre que os escritos assumem valor documental para se entenderem o contexto e os reflexos dos fatos de então.

Do ponto de vista da literatura, independente de se adotar a visão que entende os jesuítas como o ponto pelo qual "há de começar qualquer estudo da nossa poesia colonial" (HOLANDA, 1991, p. 411), o regresso aos primeiros habitantes, na fase quinhentista, torna-se possível pelos documentos da época, que servem de base a outros e assim sucessivamente, constituindo as primeiras bases de obras como as do indianismo de Gonçalves Dias e Alencar; de Macunaíma, de Mário de Andrade, e da “antropofagia” preconizada por Oswald de Andrade. Se a retomada da palavra da colônia sustenta a literatura indianista, favorece também o 
entendimento da produção escrita e do contexto de José de Anchieta. O seu momento histórico é pontuado tanto nas crônicas alheias, conforme poderá ser verificado em João Francisco Lisboa (1971) quanto, especialmente, nas suas próprias cartas, cuja perícia verbal compõe um quadro valioso e interessante de se ler, embora revele as contradições de um período atroz da história do Brasil e da própria ideologia em que se inseria o padre. E, se os escritos coloniais não são considerados como uma unidade, quanto à consideração de legitimidade, sobre ser ou não "literatura" e/ou ser ou não "nacional", merecem um espaço especial na história da literatura. E é nesse contexto que avulta José de Anchieta, padre inaciano, sendo pertencente, de certo modo, à literatura brasileira, embora o mérito dê-se menos pela natureza da obra e mais pelos atributos que associavam o elemento lúdico da arte à história da colônia.

\section{Anchieta: arte, bases e sentidos}

Anchieta vem à colônia na missão da Companhia de Jesus, no período em que a colonização sobrevive à custa do flagelo da escravidão do gentio e do africano. O estudo da produção do jesuíta, as elaborações do período e as próprias teorias sobre a literatura trazem subjacentes aos respectivos discursos as vozes das suas ideologias. Lembrando as forças de poder concorrentes da época, os colonos, a corte portuguesa, os missionários e demais viajantes não vieram apenas povoar e fazer prosperar a terra e seus habitantes. Conforme lembra Le Goff sobre a exploração da América pelos espanhóis, também nossos preciosos minérios "modernizaram uma ciência econômica que já não era medieval" (2008, p. 117), sabendo-se que os interesses giravam em torno da possibilidade exploratória do Brasil e em toda a América. Alfredo Bosi, citando Pero de Magalhães Gândavo, diz que sua obra História da Província de Santa Cruz, a que vulgarmente chamamos de Brasil, termina "com uma das tônicas da literatura informativa: as preocupações com o ouro e as pedras preciosas que se esperava existissem em grande quantidade nas terras do Brasil” (BOSI, 1974, p. 20). O foco também se torna a conversão do gentio, cujos objetivos variam conforme o agente que atuava na colônia e na corte.

Nas circunstâncias do período, José de Anchieta, como bem lembra Silvio Romero (1960), foi um jesuíta apaixonado e devotado. A simplicidade e a diplomacia de Anchieta são evidenciadas na escrita culta, que lhe revelou também a visão diferenciada sobre o panorama missionário de então, distinguindo-se dos outros pela investidura humana, embora limitada pela servidão à Companhia. Suas opções doutrinárias revelam de modo central a transmissão dos fatos religiosos por meio de autos pastorais, criados por ele mesmo. Um exemplo dessas criações é o Auto de São Lourenço (ANCHIETA, 1997a), peça encenada para ensinar os 
princípios católicos e corrigir os costumes politeístas. Como dramaturgo, na referida peça, ele faz na verdade uma rapsódia, em que cria episódios sem uma cronologia sequencial nem uma unidade na trama. Articula cenas em analogia como a vida dos indígenas além de alguns fatos históricos e outros ocorridos no período, numa técnica de fragmentos e superposições. Certamente não sabia o padre, na intenção de salvar os chamados "fetichistas", a complexa problemática do seu projeto. Um aprofundamento da questão que envolve o empenho dos jesuítas em transformar a cultura daquele povo, mudar seus hábitos, crenças e costumes, evidencia um fenômeno que ultrapassa os limites concretos do seu modo de viver. Envolve outras questões substanciais dentre as quais o componente psíquico, a identidade e a tradição, centralizados pela força das suas crenças. E uma representação que propõe uma possível consequência decorrente dessa tentativa de interferência e mudança profunda encontra-se na obra Maíra, de Darcy Ribeiro (1976).

A história de Maíra trata do personagem Avá, membro da tribo mairum, que é enviado a Roma para ser convertido à fé católica. É então batizado com o nome de Isaías, quando é considerado pronto a voltar à sua tribo. Porém, volta confuso e triste. Como se pode ler na obra, ele retorna a sua tribo sofrendo de uma "ambiguidade essencial”, apresentando-se alheio a sua origem, com espírito desconexo e identidade indefinida. $\mathrm{O}$ futuro ao qual estava predestinado pela tradição e a importante relevância do seu papel para seu povo sucumbem junto com seu espírito. Teidju, o curandeiro da tribo, diz não saber o que será de Avá. Explica o resultado da educação religiosa recebida: “[p]ara isso se preparou anos-e-anos. Voltou e não é oxim, nem nada. Tuxaua devia ter sido, mas não serve. Se vê na cara dele que é torcido. Nunca, nunca será um tuxaua.” (RIBEIRO, 1976, p. 283). Também outra personagem, Alma, diz: “[o] mal de Isaías é ser ambíguo. Não é índio nem cristão. Não é homem nem deixa de ser, coitado. Ser dois é não ser nenhum, ninguém. Mas está acima de suas forças.” (RIBEIRO, 1976, p. 374-5). Seu estado, segundo ela, é o de viver a "escarafunchar a cuca, se aclarando e se confundindo cada vez mais" (RIBEIRO, 1976, p. 375).

Não poderia também esperar um engajamento natural deles na sua ideação, fato talvez aplicável à seguinte explicação segundo a qual:

para esperar que o incrédulo possa ser instado a decidir-se a crer porque lhe tem sido demonstrado por razões coercitivas que aquele que aposta na existência de Deus arrisca um investimento finito para ganhar lucros infinitos, seria preciso acreditar que ele está suficientemente disposto a crer na razão para se mostrar sensível às razões dessa demonstração (BOURDIEU, 2001, p. 22). 
Mais ou menos próximas a esta explicação, as estratégias de envolvimento eram variadas, sendo que Anchieta parece ter tido plena consciência do poder da arte. Do ponto de vista da técnica formal, de certo modo, no auto o todo se refrata em partes, para então reuni-las na temática global, o que seria o retrato da própria circunstância da vida naquele momento. Sem intenção, o jesuíta revela o, por assim dizer, "surrealismo" do que ocorria no campo concreto e no abstrato, em que o selvagem se vê inoculado dos sentimentos de culpa, pecado e salvação, ao mesmo tempo em que são invadidas e tomadas suas terras. Se se pensar bem, é também o surrealismo da subordinação de uma cultura harmoniosa em seus valores e mesmo contradições, submergindo-se à aculturação pela inoculação de outras crenças e sistemas.

Nesse Auto de São Lourenço há trechos de pregação, de referência à luta contra invasores estrangeiros, para dançar e cantar em procissão, cujos versos articulam trechos da "rapsódia e visam a converter recreando" (BOSI, 1974, p. 26). O Anjo, personagem do auto, representa aquilo que cai como luva ao que se pretendia do selvagem, a interação simbólica entre Amor e Temor, corporificados nos versos. O fogo justifica o nome do mártir "São Lourenço". O indivíduo seria convertido por acreditar, conforme quer Anchieta, tornar-se, ao contrário do fétido demônio, o ser transformado pela salvação e exalando agradável aroma, seria

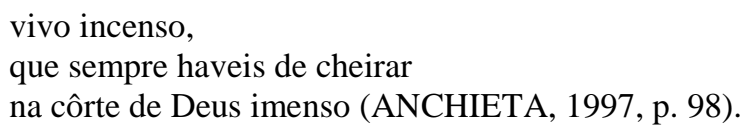

Por meio do martírio de São Lourenço, representa-se a salvação do "infiel". E, na pedagogia de introjeção e conversão do politeísta, busca-se promover o espelhamento do aborígine com o demônio:

\author{
Sou Guaixará embriagado \\ sou boicininga, jaguar, \\ antropófogo, agressor, \\ andira-guaçu alado, \\ sou demônio matador. (ANCHIETA, 1997, p. 59)
}

$\mathrm{Na}$ tentativa de convencê-los da natureza viciosa de certos costumes tribais, o procedimento visa a ridicularizar esses costumes e, portanto, a modificá-los. E, toda a dinâmica do poema, ainda que não muito articulado, constrói-se no intuito de formar os dois polos da tensão entre o bem e o mal, com atributos que se contrapõem a vícios, como, por exemplo, se o anjo é cheiroso, o demônio é fétido. Se o anjo é lúcido, o demônio embriaga-se (do cauim), se o anjo protege seu semelhante, o demônio come-o. O demônio torna-se a condensação do 
que considera vícios indígenas. Por isso, a função de conversão e mudança de costumes. Ao final, confirma-se São Lourenço martirizado como protetor dos nativos e a dança tem sentido de comemoração da vitória do bem.

Também versejou sua devoção a mulheres santas, sobretudo à Virgem Maria, e a musicalidade também se apresenta de modo a facilitar o envolvimento do primitivo. Assim, nos poemas, a devoção embalada, sobretudo ao ritmo estabelecido na medida velha, usa a arte como recurso didático e incentivo à fé. A linguagem simples também atua de modo a buscar maior eficácia. Cotejando as faces do dramaturgo e do poeta, Alfredo Bosi diz que se os autos de Anchieta destinam ao ensinamento eclesial, na "edificação do índio e do branco em certas cerimônias litúrgicas (Auto Representado na Festa de S. Lourenço, Na Vila de Vitória e Na Visitação de Sta. Isabel), o mesmo não ocorre com os seus poemas que valem em si mesmos como estruturas literárias" (BOSI, 1974, p. 23).

Nos versos à Santa Inês (ANCHIETA, 1997, p. 34-8), virgem que foi decapitada por "não perecer à perdição do corpo e manter-se virgem", revela-se a dicotomia entre dois estados contrários, cujo marco divisor é a chegada da cabeça da Santa. Sua presença carrega o efeito de espantar o mal, alimentar o espírito e revigorar a fé do povo. O processo se dá pelas metáforas do "trigo", do "pão", pela função da "padeirinha" cuja pureza ("trigo sem farelo") alimenta a alma e espanta o diabo. Sua pedagogia jesuítica ensina que o martírio purifica o corpo, impregnando a vida da ideia de que, pelo sofrimento, seria facultada a salvação da alma. Também a simplicidade e o desapego recebem o foco nos seus versos:

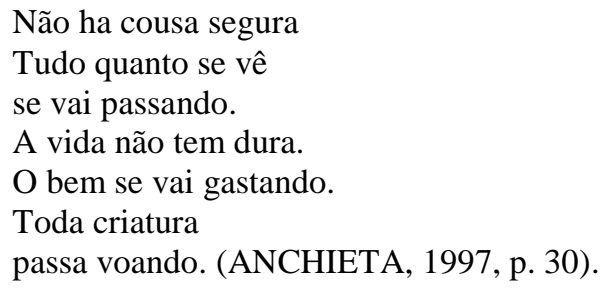

E nos versos em que enaltece o alimento:

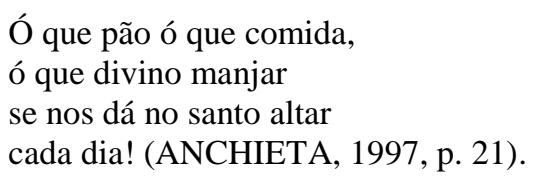

Ficam patentes os significados que ligam a valores religiosos e a santificação dos elementos sagrados, dos seus sacramentos e preceitos. A lealdade do jesuíta torna-se um atributo, uma boa qualidade sobre certo ponto de vista. Mas o exercício mental que se procede 
ante a expressão e a sua realidade sai do campo do simples e entra no campo do abstrato. Tornase instigante entender que a crença que motivou o catequista a fazer os versos acima, em outros tempos, poderia ter-lhe facultado o entendimento da simbologia cultural indígena, essa que, segundo Darcy Ribeiro (1996), diferentemente do colonizador, possuía "estrutura social igualitária" (p. 34). Nesse ponto, a leveza se transforma em certo desconforto pesado. O efeito estético para o leitor moderno tende a se modificar quando se tem em mente a quem se dirigiram os versos. O alimento dessas culturas era outro. Suas ambições também. Nesse caso, concordase com Silvio Romero que arrazoa: "um filho de Loiola não pode ter idéias suas. É um ente que se anula para melhor devotar-se" (ROMERO, 1960, p. 351). José de Anchieta, embora figura singular e diferenciada, faz parte da engrenagem que se formou quando se lançaram as bases do país de hoje, no momento do caldeamento moral e étnico.

Porém, se os poemas de Anchieta são genuínas estruturas literárias quanto à forma, o efeito estético deles torna-se digno de ponderação e, em várias configurações dele mesmo, apresenta-se diferente potencial pathêmico. É comum a percepção de que a maior qualidade da sua obra consiste na singeleza. É o caso dos versos sobre a chegada da imagem da cabeça da Santa Inês, cujo ritmo melodioso e cuja regularidade na alternância das tônicas e átonas, no clima de carinho criado, embalam o leitor.

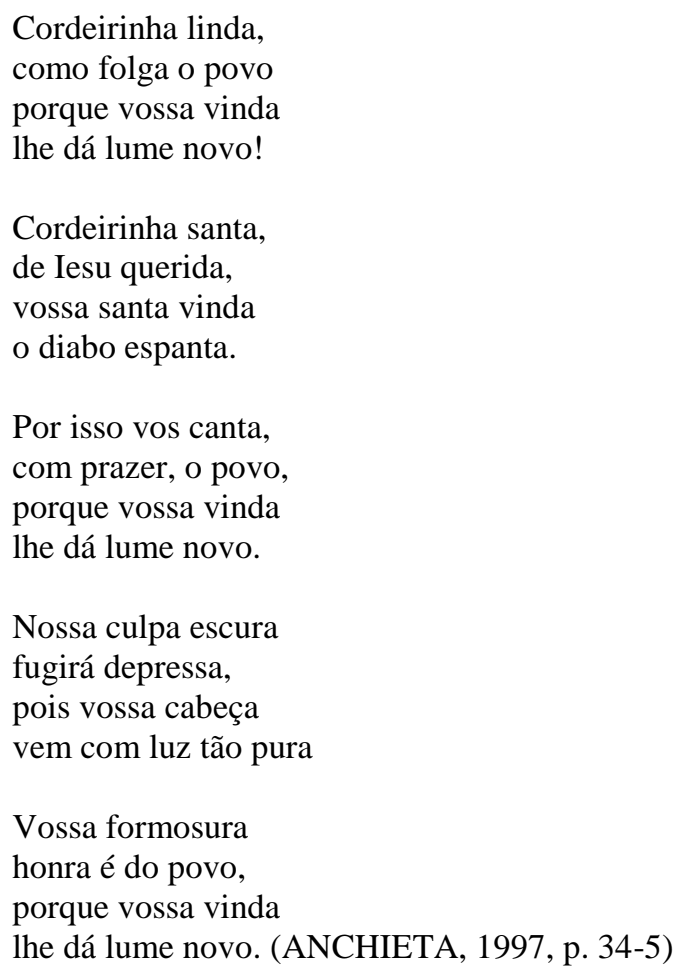


A símile das duas faces, claro e escuro, bem e mal, culpa e pureza, santo e diabólico, nos pentassílabos, revela a transformação promovida pela chegada da cabeça da Santa Inês. Ela exorciza o mal e traz luz ao povo, no qual ela atuaria alimentando o espírito e revigorando a fé. A linguagem é clara, as ideias são facilmente compreensíveis e o ritmo faz com que os versos tenham musicalidade, ajudando a envolver e sensibilizar o ouvinte para sua mensagem religiosa.

Mas, embora leve e singelo, de agradável melodia no ritmo regular, um posicionamento possível sobre o poema é de que ele carece daquele elemento que reflete a propriedade explicada por Antonio Candido como "a capacidade de penetrar nos problemas da vida" (CANDIDO, 2004, p. 180), no sentido de que, por mais que o gentio fosse considerado em espírito, a mudança de crença não se processa tão simplesmente e nem acontece. Toda a tentativa nesse processo não poderia ocorrer, caso possível, sem sofrimento. A crença que sustenta a mensagem do poema, vista hoje, encontra um certo vazio, nesse ponto de vista pathêmico, reforçado, hoje, pelo ethos que os catequistas assumiram. Do mesmo modo acontece no poema "Do Santíssimo Sacramento":

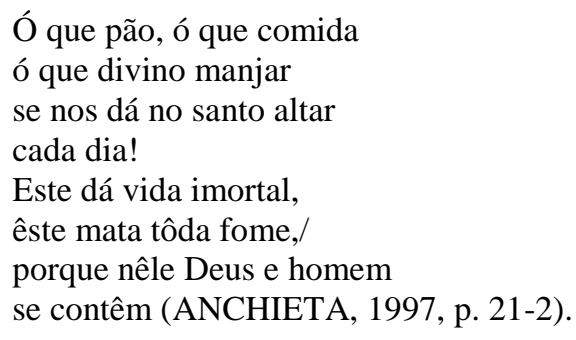

A comunhão do português se estende ao silvícola e, segundo o próprio jesuíta relata, durante a Eucaristia, revelam-se vários deles “capazes do Santíssimo Sacramento, que recebem com grande devoção" (ANCHIETA, p. 329). E, a não ser no caso de um espírito que se toca e se emociona com a simbologia dos ritos e das imagens consideradas sagradas no catolicismo, o assunto limita a abordagem. A cabeça da santa traria luz para o povo, criando paradoxalmente à postura de Anchieta, uma relação que não deixa de ser totêmica. A imagem iluminaria a escuridão e salvaria o povo do demônio. Mas o ponto a que se quer chegar é que, no poema, embora haja uma isometria nos versos, sugere uma assimetria relacionada à beleza que, se levado em conta o que diz Mário de Andrade, em relação a algumas obras que se julgam superiores devido à mensagem humanística em detrimento da forma, aplica-se, grosso modo, aos poemas de Anchieta, que podem ser ponderados pelo inverso da síntese do "essencial" que explica Mário de Andrade, em “A raposa e o tostão” (2002). Segundo ele, é a forma que atribui 
o valor de uma obra, mas o assunto é inerente e deve ser humanamente válido tanto quanto a forma deve ser esteticamente válida. Diz ele:

\footnotetext{
Que o assunto seja, principalmente em literatura, um elemento de beleza também, eu não chego a negar, apenas desejo que ele represente realmente uma mensagem, como na obra de um Castro Alves. Quero dizer: seja efetivamente um valor crítico, uma nova síntese que nos dê um sentido da vida, um aspecto do essencial (p. 110).
}

Ele diz que a forma associa-se ao assunto para se criar uma bela obra. Ressalta-se aqui que o assunto, em movimento inverso, é indissociável da forma, pois, conforme Mário de Andrade, sendo um valor crítico, esse dá "o sentido da vida, um aspecto do essencial”, estando ligado ao bem e ao amor. E, voltando ao poema da "Cordeirinha" Santa Inês, a magia da imagem da santa, atuando na mente do indígena e do colono, não toca o essencial do fato, pela complexidade do problema descrito, inclusive, na vertente sociológica de Antonio Candido, uma vez que visa a impossível missão de atuar psiquicamente com base nos valores de uma cultura e obliterar os valores da outra, como se tal mudança fosse possível.

Diante do exposto, ainda que respeitando o valor da poética de José de Anchieta, tomase uma posição paralela com a opinião de Silvio Romero, no entendimento de que "o melhor patrimônio que êle nos legou, como escritor, são as suas despretensiosas cartas" (1960, p. 353). No que se refere ao essencial, percebe-se que a palavra de Anchieta torna-se mais significativa exatamente onde não se delineia uma intenção estética: nas missivas. Nas epístolas enviadas com informações da colônia, o jesuíta revela, embora com as contradições e ressalvas ideológicas da sua subserviência à Companhia, a alma doce, humana, inteligente e distinta. Então, nesse campo também, ele se distingue entre tantos missionários que vieram para difundir a fé católica. Torna-se interessante aquela escrita de cunho social, que lhe revela os valores e pontos de vista, sua individualidade e distinção, bem como os problemas referentes ao seu tempo e ao seu condicionamento religioso e ideológico. Uma comparação entre suas epístolas e sua poética esclarece o que se quer dizer, uma vez que guardadas as devidas proporções e o efeito estético, a questão da doutrina está presente em ambos. Tome-se, por um lado, os referidos versos:

\footnotetext{
Cordeirinha linda como folga o povo porque vossa vinda lhes dá lume novo.
} 
Por outro lado, o trecho de uma epístola, cujo efeito normalmente giraria em torno da função de informar sobre a catequese dos selvagens, mas que, perceba-se, modifica-se pelo modo de ver e de dizer:

\begin{abstract}
Acompanharam algumas vezes nas guerras justas os governadores e capitães onde remedeiam as almas dos portuguêses, e dos escravos e índios, batizando e confessando, e além disso por seu meio se tem alcançadas vitórias mui notáveis estando o português em evidente perigo de serem destruídos, como se viu na guerra que fez Antonio Salema ao Cabo Frio, onde na primeira aldeia que era fortíssima e da melhor gente que havia em tôda a terra que estava ali junta, estavam já em grande tribulação e o índio principal dela, ouvindo e conhecendo as palavras de um nosso padre, se entregou a si e a tôda a aldeia e dali se sujeitou todo o Cabo Frio sem trabalho" (apud ROMERO, 1960, p. 357).
\end{abstract}

Anchieta enxerga o modo alienado e alienante como era realizado o sacramento do batismo do gentio pelos missionários, criticando a desconsideração da sua inteligência, reforçando que o padre afirma nas referidas cartas a coerência do povo indígena mais próxima à conduta cristã do que muitos portugueses. Mas, como se percebe, a engrenagem cultural e religiosa dá conta das suas tarefas chamadas à responsabilidade e impulso doutrinário de então, quase sem questões e sem resistência ideológica que a fragilizem.

Percebe-se a angústia do jesuíta, que relata o problema do batismo "mecânico", realizado por alguns missionários e que, no entanto, o fazem sem explicação ou qualquer esclarecimento ao aborígene que o recebe. Percebe-se a distinção do padre, que denuncia, em outras palavras, a alienação com que alguns veem o primitivo, considerando-o sem alma. Anchieta toca no "essencial”, ou seja, na consideração do teor humano da consciência, evidenciando nesse ponto específico os fundamentos que alicerçarão o que Paulo Freire viria tratar mais tarde pelo nome de "pedagogia do oprimido" (FREIRE, 2014). O ensino dialógico e as bases sobre a pedagogia do colonizador, que Freire apoia, Anchieta defende já naquele tempo. Mas, como se observa, a sensibilidade humana em outros pontos contradiz-se.

O que se pretende demonstrar é que, de certa forma, o teor essencialmente válido do comportamento demonstrado em significativas elaborações do Padre Anchieta relaciona-se em paradoxo com o seu condicionamento ideológico. Até a produção artística fragiliza-se tanto pelo objetivo como pelo conteúdo. O próprio Anchieta, ao expor a participação e a contribuição dos missionários na captura dos nativos, traz à tona as contradições de que participou. A "guerra justa" usada como justificativa do jugo é registrada por ele, bem como seu endosso, e afigurase natural na escrita. Sobre a Guerra justa, cujos fundamentos remetem aos pressupostos das Cruzadas, o padre Antonio Vieira também, no século seguinte ao de Anchieta, expressaria tal naturalidade em muitos pontos da sua oratória, como, por exemplo, ao defender que se 
pudessem manter como escravos aqueles gentios que fossem presos por "guerra justa". Em suas prédicas, a aceitação da guerra ocorre, por exemplo, no "Sermão da Primeira Dominga da Quaresma" (VIEIRA, 2001), em que o orador adverte os donos de escravos indígenas sobre o pecado do cativeiro como praticavam, mas os tranquiliza com uma proposta que tornaria lícita algumas espécies de mão de obra indígena, tanto a mão de obra livre daqueles que se voluntariassem para servir os portugueses como daqueles que, presos em guerra, fossem cativos, ou seja, de quem a mão de obra era, de um modo ou outro, imposta:

\footnotetext{
De sorte que nesta forma todos os Índios deste Estado servirão aos Portugueses, ou como própria e inteiramente cativos, que são os de corda, os de guerra justa, e os que livre e voluntariamente quiserem servir, como dissemos dos primeiros; ou como meios cativos, que são todos os das antigas e novas aldeias, que, pelo bem e conservação do Estado, me consta que, sendo livres, se sujeitarão a nos servir e ajudar a metade do tempo de sua vida (p. 463).
}

Tomando ciência pelos registros do próprio sujeito do relato, ainda hoje repercutem a perplexidade e as cicatrizes dessa ação colonizadora e catequista, cujo distanciamento deve estar ponderado pelo embaçamento inevitável dos fatos. Não resta dúvida de que a distinção do ilusionista da palavra, como Vieira foi considerado por muitos estudiosos, revela a arte e diplomacia do orador, mas revela também suas concepções e valores, o que se associa à ideia de Afrânio Coutinho quando esse diz que "a forma está correlacionada à visão de mundo" (COUTINHO, 2004, p. 307), o que certamente liga-se ideologicamente em correspondente natureza conforme o contexto, tornando-se inevitável ponderar o contexto em que os fatos ocorrem.

A posição sobre a "guerra justa", então, endossa o cativeiro, associando Vieira a Anchieta, e reitera o fenômeno do efeito pathêmico adverso no percurso da leitura das cartas: o olhar sobre o relato da captura de indivíduos sentenciados como prisioneiros e o modo como Anchieta relata ativam no leitor do Século XXI a sensibilização e a lúcida contraposição. Assim, mesmo que sem a intenção, a reação potencial a Anchieta tende a ser mais intensa diante das cartas do que na sua poética. Isso porque nas cartas o choque se dá na constatação de que falta no jesuíta a consciência da dimensão do mal causado ao primitivo. Ainda que expresse a atuação de amenizar o embate, tomando por pacífica a sujeição de indivíduos, provoca a contradição de considerar que a ausência de violência física faria da sujeição sem resistência um processo pacífico. Ou seja, desconsidera, não aborda, parece não ver a profunda violência que se empreendeu, e aqui se reitera, sem entender os argumentos aqui lançados como paradoxais, que sua ação não deixou de amenizar os maus tratos e o modo como os seus pares entendem os 
povos originários, ou seja, como destituídos de alma. Assim, se o "essencial” humano, ou seja, o que toca o amor e o respeito ao semelhante, e a visão do poeta revelam-se superiores em algumas cartas e em outras não, José de Anchieta revela-se atento à necessidade de conscientização dos portugueses e missionários quanto ao respeito que o nativo deveria merecer. Insiste em que a gente do novo mundo não é um povo sem alma. Também defende esses habitantes da violência do estrangeiro e dos sacramentos mecânicos das curas, alguns deles realizados em latim, de forma alienada. Nesse sentido, busca legitimar as ações religiosas pela natureza humana dos tupinambás, revelando o erro de considera-los animais irracionais e sem alma. Mostra com isso uma distinção essencial que, como vem sendo dito, por outro lado, fragiliza-se de modo geral diante dos poemas, autos e cantos, uma vez que esses revelam a repressão do modo de existência dos gentios catequizados. Sua intervenção na cultura politeísta, antropófaga, polígama dentre outros costumes, choca-se com a sublimação benevolente da sua missão, devido à sua outra face, de sentido doutrinário e dogmático, que ensina ao íncola a elevação espiritual com base na culpa de ele ser o que é e crer no que crê. Os poemas podem ser considerados belos, sobretudo levando em conta o contexto e a ideologia da aliança entre Igreja e Estado. Mas, do ponto de vista social, cultural e humano, a forma como se buscou execrar os costumes tupinambás delineou um conflito cujas implicações diversas se reafirmam em suas consequências, desastrosas para aquela população.

Desnecessário dizer que a validade estética, portanto, vem à berlinda, pois sendo a forma indissociável do conteúdo e, no caso da literatura, que tem como matéria-prima a palavra, a técnica é elemento que se une ao assunto para que o resultado seja uma bela mensagem, antagoniza a si mesmo pela complexidade da imposição do uso, do modo de pensar, valorar e evidenciar os problemas do indígena. Todo o fenômeno ocorrido na catequese dos jesuítas parece girar em torno do modo de ver e de ser, lembrando o que diz Bourdieu na seguinte assertiva:

\footnotetext{
O processo de diferenciação do mundo social conducente à existência de campos autônomos concerne, ao mesmo tempo, ao ser e ao conhecer: ao se diferenciar, o mundo social produz diferenciações dos modos de conhecimento do mundo: a cada um dos campos corresponde um ponto de vista fundamental sobre o mundo que cria seu próprio objeto e encontra nele mesmo o princípio de compreensão e explicação conveniente a esse objeto (BOURDIEU, 2001, p. 120).
}

O fato se revela mais adverso ainda pelo modo como os indivíduos podem atuar nessa justificativa de diferenciação, como aconteceu na catequese. $\mathrm{O}$ teor do caso acentua-se quando tange o caráter didático dos autos, cujo pathos está mais ligado à pedagogia do padre do que à 
forma da sua escrita, lembrando-lhe o traço do proselitismo pelos preceitos da militância inaciana. Por isso que cria o paradoxo de entender a natureza humana e mental dos membros das tribos na colônia, mas não consegue realizar uma ação que faça jus a esse entendimento. Contudo, as ponderações não diminuem a sua posição no pioneirismo das manifestações literárias nos primórdios da história do país nem põem em cheque a então distinta sensibilidade. De fato, ele se opôs à força bruta envolvida no contexto concorrencial do interesse puramente mercantil, em que muitos vestiam o manto da religião como arma para ampliação do poderio material. De modo inequívoco, não é o caso de Anchieta.

Porém, sua intenção não ameniza o fato de que a leitura acarreta uma sensação de mãos atadas, a percepção de uma mente que, mesmo distinta, é ideologicamente regida pelos mesmos pressupostos doutrinários da talvez mais negra fase da engrenagem católica. O desconforto se intensifica se procedida a analogia com as injustiças do mundo atual. E ainda mal é sentir que Anchieta é feito, ao contrário da maioria com quem conviveu, de coração e mente, de "boa matéria”, bons sentimentos. E sua maior fragilidade pode estar ligada à mesma natureza factual com que supôs salvar os aborígenes, a sujeição do homem à crença. O motivo, ao que parece, deve-se ao fato de que, hermeticamente leal à Companhia, não se permitiu enxergar o paradoxo que de fato aconteceu, como no trecho recortado por Silvio Romero, relatando trabalhos julgados exitosos dos missionários, revelando a rendição de aldeias aos portugueses:

O mesmo foi na capitania do Espírito Santo: estando quase todos os moradores sôbre uma forte aldeia daí 30 léguas, já desconfiados e em perigo de se perder, pelas palavras de outro nosso padre se entregou aquela aldeia e outras (apud ROMERO, 1960, p. $357)$.

O padre insere-se no contexto em que o método originário das Cruzadas leva a que o colonizador arvore-se em juiz e estabeleça condições para a aceitação da guerra como justa, o que se fazia em associação com a palavra de Deus. Tais relatos demonstram alguns dos meios das missões e, após as citações feitas, Anchieta refere-se à outra rendição, por intercessão de um padre que "trouxe consigo algumas 600 almas de índios, passando grandíssimos trabalhos e perigos, dos quais índios se fez uma das aldeias do Rio e são já quase todos cristãos”. (apud ROMERO, 1960, p. 357). Associe-se a conversão ao trabalho indígena forçado e têm-se o paradoxo.

Com relação à face estética, aproveitasse ele a matéria mais preciosa que tinha para tanger o amor, a técnica e a crítica, e sua individualidade de aguda visão tocaria não pelo pioneirismo e perícia da palavra, mas por associar o grande coração, a aguda visão e a hábil palavra à 
libertação do homem da nova terra. Essa consiste na falta que esta escrita intenta definir: associar a estética à política (no real sentido da palavra). Em sua militância, embora tenha se empenhado em defender as aldeias e seus membros, que via sacrificados, lança um olhar de distanciamento, por exemplo, em relação aos personagens bíblicos. Seus versos místicos, sobretudo o marial, não aproximam sua adorada Maria do mundo terreno, num plano mais tangível. Mas seu estilo e relação com Maria e outras santas consiste em dado pessoal, espelhando a devoção e diferenciando-se de outros missionários. Exemplo disso pode ser outro paralelo entre o que ele, Anchieta, escreve no poema "Do Mistério do Rosário de Nossa Senhora" e o sermão XIV, que Antônio Vieira faz aos pretos de um engenho. Nesse, Anchieta reverencia Nossa Senhora e, percorrendo o suplício de Jesus, proclama reiteradamente o caráter inatingível de Maria, a cada estrofe: "Que habitante do mundo há como tu?" (ANCHIETA, 1997, p. 116-127). Já Vieira, associa o homem a personagens bíblicos e, em sua lucidez humana, nivela, por exemplo, os escravos africanos, lado a lado com Cristo. $\mathrm{O}$ africano escravizado no engenho num sermão também do Rosário, por exemplo, é comparado por Antônio Vieira, em 1633, com Jesus. Diz ele que, como Jesus, eles sofrem e, como Jesus, são filhos de Maria. Comparando ambos, o misticismo de Anchieta torna o elemento divino inatingível ao homem, enquanto a fala de Vieira aproxima o escravo do divino: "padeceis em um modo muito semelhante ao que o mesmo Senhor padeceu na sua cruz, e em toda a sua paixão. A sua cruz foi composta de dois madeiros, e a vossa, em um engenho, é de três" (VIEIRA, 2001, p. 651). Fica a sensação de que, em Anchieta, à militância proposta pela Companhia faltou o traço da veia libertária, o estímulo à veia crítica do indígena, no sentido de se situar e situar a ação dos portugueses. Nesse ponto, o auto de São Lourenço revela um fato paradoxal, pois se os imperadores Décio e Valeriano foram matadores, é porque a esses faltou, tanto quanto ao português, o desapego descrito por Anchieta:

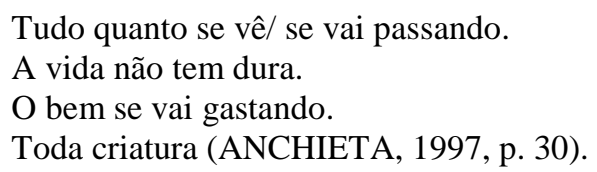

O discurso maniqueísta doutrinário que subjaz à sua catequese consiste em um fator a subtrair suas qualidades de leveza e singeleza da sua poética, pois traz à memória as atrocidades contra o habitante de Pindorama, sob o pressuposto da antirreligião dos costumes indígenas, o que ocorre não apenas no Auto de São Lourenço, mas em vários escritos do padre, que vê no modo de vida do primitivo as trevas e a condenação. 


\section{Considerações finais}

A sensibilidade e a individualidade do jesuíta José de Anchieta resultam numa dedicação extrema e fervorosa, pensando salvar a gente do Brasil. Tais atributos, porém, anulam-se quando se trata de ir contra a doutrina inaciana e aos interesses reinóis a que servia. E se, por um lado, como jesuíta, anulou sua individualidade; por outro lado, foi considerado distinto, conforme afirma Capistrano de Abreu, para quem ele era um penetrante psicólogo (ABREU, 1988, p. 27) de outros jesuítas do seu tempo, por sua simplicidade e visão mais sensível.

Nas cartas, como se viu, informa aos superiores na Europa o que se passava nas missões. Como finalização, evoca-se a missiva em que ele relata a visão que vários jesuítas tinham dos habitantes da terra, como seres sem almas e aqui se cita como encerramento que reforça o equívoco então vigente: “com os índios livres visto está que se não faz diligência alguma no que toca a sua salvação, quase como de gente que não tem alma racional nem foi criada e redimida para a glória." (ANCHIETA, 1988, p. 330). Revela com isso que, em meio aos preconceitos da época, conseguia ver o equívoco dos pressupostos que motivam a marginalização do autóctone. Em defesa do homem natural, Anchieta, mesmo julgando necessária a transformação cultural e religiosa desse povo, considera-o menos pecador em comparação com o português que o subjuga. Ilustra esta comparação dando o testemunho, tanto pelo que presenciou como pelo que escutou deles, de que os piores defeitos desses povos originários foram adquiridos pelo contato com os lusos: "quanto à vida, não tenho dúvida que excede à maior parte dos portuguêses do Brasil, porque muito menos pecados cometem que êles, e os piores nesta parte são os que com êles têm mais trato e isso se lhe pega de sua conversação e exemplo.” (apud ROMERO, 1960, p. 357).

Ao "essencial" indispensável na literatura, relaciona-se a manifestação de Anchieta na nova terra, aproximando-o e afastando-o. O jesuíta inconsciente ou conscientemente, atua em outro âmbito, no sentido em que pode ser visto como participante da semente que hoje ainda dá frutos, mas que já se havia plantado. No imaginário do brasileiro, ela sobrevive até hoje. Certos valores ainda levam remanescentes indígenas ao centro da culpabilidade: julgam-lhe o mérito na sociedade civilizada, estabelecem, ainda na dicotomia civilizado - superior / "selvagem" inferior, delimitam o que é lícito ou não. E a posse datada de maio de 1500, na famigerada confusão com propriedade, às vezes inverte os papeis, como numa intifada, em que o desterrado tenta se rebelar. Dão-lhes cotas, roupas, terrenos, mas a concepção de marginalidade e exotismo não se supera. Pior que marginalidade, fica a sensação de estorvo, quando se percebe na atitude de muitos que, se alguns sobreviveram, permaneceram "em detrimento" da propriedade. Assim, 
de nada adianta a beleza, força e nobreza com que um Gonçalves Dias tenta firmá-lo. A literatura, sendo um modo de dizer, reflete modos de ser e de pensar. E o primeiro habitante do território brasileiro, presente na literatura, em variados graus entre real e idealizado, não cabe no pensamento do civilizado, mesmo que tenha cabido no pensamento ficcional da poesia. $\mathrm{E}$ aqui se adota uma ideia de Antônio Sérgio, citada por Augusto Meyer a respeito de Antônio Vieira, mas que cabe direto na situação em que se insere Anchieta, segundo a qual o canarinho "se bem apurarmos as contas, acabou na verdade por pactuar com as injustiças. Que digo? Pactuar? Não; mais do que isso, infelizmente: acabou por servi-la (apud MEYER, 1986, p. 287). E a literatura, embora não conscientemente violenta, serviu simbolicamente como instrumento de opressão por representar "pacificamente" a contraposição aos seus hábitos e crenças, na busca de eliminar sua memória, seu passado e ritos, enquanto inculcou as noções de culpa e pecado.

\section{Referências}

ABREU, Capistrano de. A obra de Anchieta no Brasil. In: ANCHIETA, José de. Cartas, informações, fragmentos históricos e sermões. Belo Horizonte / São Paulo: Itatiaia / Edusp, 1988, p. 23-8.

ANCHIETA, José de. Poemas - Lírica Portuguesa e Tupi. São Paulo: Martins Fontes, 1997. Auto de São Lourenço. Adaptação de Walmir Ayala. Rio de Janeiro: Ediouro, 1997a.

ANDRADE, Oswald. Manifesto antropófago. Revista de Antropofagia. 1928-1929. Edição fac-símile, São Paulo, v. 1, p. 7, 1974.

ANDRADE, Mário. A Raposa e o tostão. In: ANDRADE, Mário. O Empalhador de passarinho. Belo Horizonte: Itatiaia, 2002, p. 105-11.

BOSI, Alfredo. História concisa da literatura brasileira. 2 ed. São Paulo: Cultrix,1974.

BOURDIEU, Pierre. Meditações pascalianas. Rio de Janeiro: Bertrand Brasil, 2001.

CAMINHA, Pero Vaz de. A Carta do descobrimento. Pesquisa bibliográfica: Domingos de Oliveira. Correio da Bahia, s/d.

CANDIDO, Antonio. Formação da Literatura Brasileira. Belo Horizonte: Itatiaia, 1981.

CANDIDO, Antonio. O direito à literatura. In: CANDIDO, Antonio. Vários escritos. São Paulo/Rio de Janeiro: Duas Cidades/Ouro sobre Azul, 2004, p. 169-191. 
CARDIM, Fernão. Tratados da terra e gente do Brasil. Rio de Janeiro: J. Leite e Cia., 1925.

COUTINHO, Afrânio. A Literatura no Brasil. São Paulo: Editora Global, 2004. v. 2.

FERNANDES, Dirce Lorimier. A inquisiçãa na América durante a união ibérica (15801640). São Paulo: Arke, 2004.

FREIRE, Paulo. Pedagogia do oprimido. Rio de Janeiro: Paz e Terra, 2014.

HOLANDA, Sérgio Buarque de. Capítulos de Literatura Colonial. São Paulo: Brasiliense, 1991.

LE GOFF, Jacques. Em busca da Idade Média. Rio de Janeiro: Civilização Brasileira, 2008.

LISBOA, João Francisco. Crônica do Brasil Colonial. Petrópolis: Vozes, 1976.

MEYER, Augusto. Vieira. In: MEYER, Augusto. Textos críticos. São Paulo: Perspectiva, 1986, p. 283-287.

MONTAIGNE, Michel de. Dos canibais. In: MONTAIGNE, Michel de. Ensaios. São Paulo: Abril Cultural, 1980. Coleção Os Pensadores.

RIBEIRO, Darcy. Maíra. Rio de Janeiro: Civilização Brasileira, 1976.

O Povo Brasileiro. São Paulo: Companhia das Letras, 1996.

ROMERO, Sílvio. História da Literatura Brasileira. Rio de Janeiro: José Olympio, 1960. v. 2.

VIEIRA, Antônio. Sermões. Tomo I e II. Organização de Alcir Pécora. São Paulo: Hedra, 2001.

ZERON, Carlos Alberto Ribeiro de Moura. Linha de Fé: a Companhia de Jesus e a Escravidão no Processo de Formação da Sociedade Colonial (Brasil, Séculos XVI e XVII). São Paulo: EDUSP, 2020.

Recebido em: 20/08/2020

Aceito para publicação em: 02/12/2020 